\title{
@
}

\section{An Unusual Manner Is Up to Allopurinol: DRESS Syndrome}

\author{
Allopürinole Bağlı Gelişen Nadir Bir Durum: DRESS Sendromu
}

Esra Karaman, Muhammet Gokhan Turtay, Sukru Gurbuz, Hakan Oguzturk, M. Ediz Sarihan, Serkan Bican

Department of Emergency Medicine, Inönü University Faculy of Medicine, Malatya, Turkey

\section{ABSTRACT}

Introduction: Allergic reactions can be observed in many different ways in the emergency department.

Case Report: Due to itchy skin eruptions, especially on her face and body, a 60-year-old female patient was admitted to the emergency department. It was learned from the history of the patient that the administration of allopurinol was started owing to high uric acid levels in routine examinations 15 days ago. Vital signs were stable in the physical examination. There were erosion and hemorrhagic crusts on the lips and maculopapular lesions that got pale after pressing with common erythema on the oral mucosa, face, body, and back. A dermatology consultation was asked for the patient, with a preliminary diagnosis of Drug rash with eosinophilia and systemic symptoms (DRESS) syndrome. Then, previous treatment of the hospitalized patient was stopped, and antihistaminic and systemic steroid treatments were applied. Consequently, the patient was discharged with full recovery.

Conclusion: DRESS syndrome should be considered in patients who are admitted to the emergency department with a history of using allopurinol and have skin lesions and deterioration in liver function tests showing involvement of internal organs.

Keywords: Allergy, DRESS syndrome, allopurinol

Received: 26.08.2014 Accepted: 30.09.2014

\section{ÖZET}

Giriş: Alerjik reaksiyonlar, acil serviste çok çeşitli şekillerde görülebilir.

Olgu Sunumu: Altmış altı yaşında bayan hasta özellikle yüzünde ve gövdesinde olan kaşıntılı döküntüler nedeni ile acil servise başvurdu. Hastanın hikâyesinde 15 gün önce rutin tetkiklerinde ürik asit yüksekliği saptanması nedeniyle allopürinol başlandığı öğrenildi. Fizik muayenede vital bulgular stabildi. Konjonktivalar hiperemikti. Hastanın dudaklarında erozyonlar ve hemorajik krutlar, oral mukoza, yüz, gövde ve sırtta yaygın eritemli basmakla solan makülopapüler lezyonlar mevcuttu. Hastaya eozinofili ve sistemik semptomlar ile Illaç döküntüsü (DRESS) sendromu ön tanısı ile Dermatoloji konsültasyonu istendi. Daha sonra hastaneye yatışı yapılan hastanın ilaçları kesildi, anti histaminik ve sistemik steroid tedavisi uygulandı. Hasta şifa ile taburcu edildi.

Sonuç: Allopürinol kullanım öyküsü ile acil servise başvuran cilt lezyonları olan, karaciğer fonksiyon testlerinde bozulma yani iç organ tutulumu tespit edilen hastalarda DRESS sendromu akla getirilmelidir.

Anahtar Kelimeler: Allerji, DRESS sendromu, allopurinol Geliş Tarihi: 26.08.2014 Kabul Tarihi: 30.09.2014

\section{Introduction}

Allergic reactions consist of a big part of admissions to emergency services. They can range from bare symptoms to lifethreatening conditions in various clinics. Drug rash with eosinophilia and systemic symptoms (DRESS) syndrome is a serious allergic reaction condition related to drugs and is characterized by fever, rash, and systemic signs (1, 2). DRESS syndrome, which allopurinol causes, is a serious drug reaction that is characterized by systemic symptoms. Therefore a detailed history and physical examination take an important part in the diagnosis of patients admitted with allergic symptoms. In this case, we aimed to present a patient with DRESS syndrome due to allopurinol usage.

\section{Case Report}

A 60-year-old female patient was admitted to our hospital with complaints of itchy rash, especially on her face and body. It was learned from the history of the patient that the administration of allopurinol was started as a result of high uric acid levels shown 


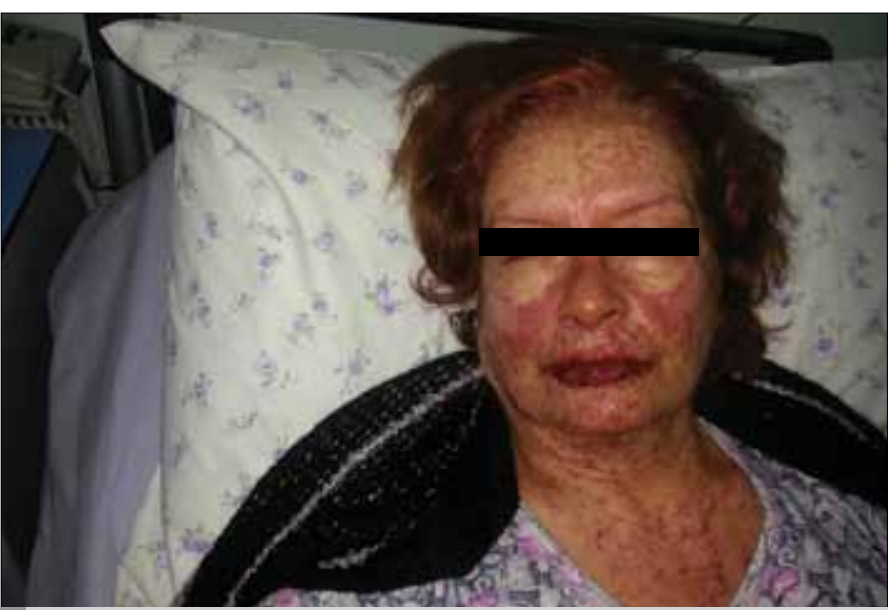

Figure 1. Erosions and hemorrhagic crusts on the lips oral mucosa, and erythematous maculopapular lesions on the face and body

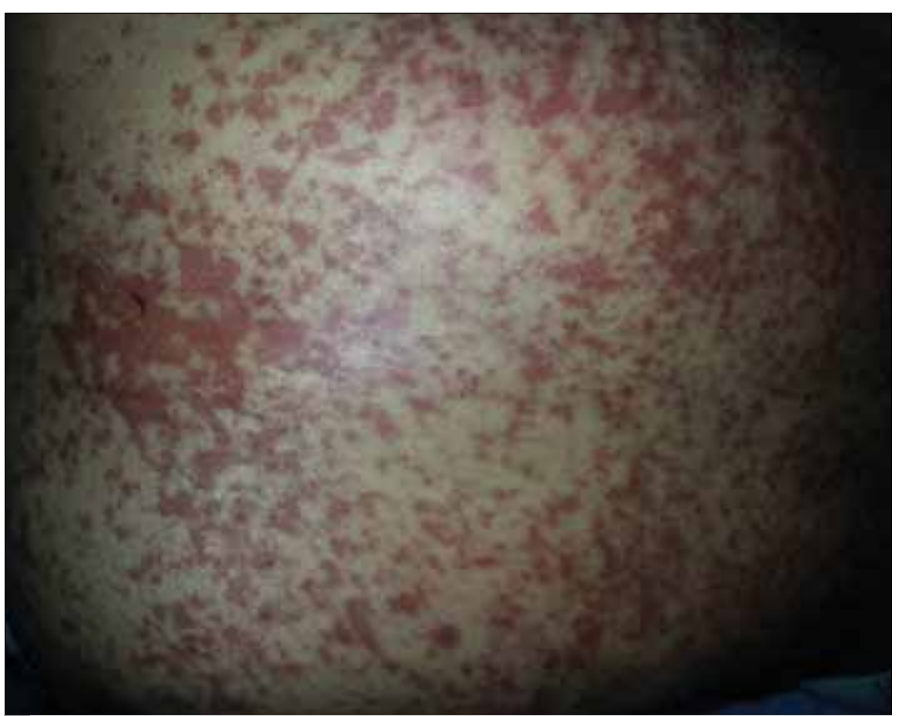

Figure 2. Erythematous maculopapular lesions on the back

in routine examinations 15 days before. Vital signs were stable in the physical examination. Conjunctivae were hyperemic. There were erosion and hemorrhagic crusts on the lips and maculopapular lesions that got pale after pressing with common erythema on the oral mucosa, face, body, and back (Figures 1-2). The laboratory tests showed glucose 136 mg/dl, aspartate aminotransferase (AST) 109 $\mathrm{U} / \mathrm{L}$, alanine aminotransferase (ALT) $171 \mathrm{U} / \mathrm{L}$, alkaline phosphatase (ALP) $423 \mathrm{U} / \mathrm{L}$, gamma-glutamyl transferase (GGT) $299 \mathrm{U} / \mathrm{L}$, lactate dehydrogenase (LDH) $312 \mathrm{U} / \mathrm{L}$, and amylase $283 \mathrm{U} / \mathrm{L}$. A dermatology consultation was asked for the patient, with a preliminary diagnosis of DRESS syndrome. Then, the previous treatment of the hospitalized patient was stopped, and antihistamine and systemic steroid treatments were applied. The patient's consent was taken, and then, she was discharged with full recovery.

\section{Discussion}

First, DRESS syndrome is a serious drug reaction that was defined in 1996 by Bocquet et al. (1). The most common causative drugs are anticonvulsant (47.4\%), antibiotics (18.4\%), NSAI drugs (15.8\%), allopurinol (5.2\%), and unidentified drugs (15.8\%) (3). In our patient, allopurinol was the causative drug.

DRESS syndrome is a condition with fever, rash, lymphadenopathy, leukocytosis, and impaired liver function. So, evaluation of skin signs and hematological laboratory tests enable a more careful investigation of the patient's drug reaction (2). In our case, rash and abnormality in liver function tests confirmed the diagnosis of DRESS syndrome.

For the diagnosis of DRESS syndrome, use of allopurinol treatment, lack of use of other drugs, and additionally, having 2 major (renal function failure, acute hepatocellular damage, rash) or 1 major and 1 minor (fever, leukocytosis, eosinophilia) criteria are required (4). In our case, hepatocellular damage and rash from the major criteria and allopurinol usage met the diagnostic criteria.

Clinical signs are observed 1-8 weeks on average after the suspected drug taken (5). Although the pathophysiology is not fully known, the causes are thought to be related to insufficiency of drug detoxification, immunological reasons, and human herpes virus 6 (1). Eosinophil activation and inflammatory cascade are possibly induced by drug-specific IL 5 is released from CD4+ CD8+ T cells (2). Oxipurinol, which is an active metabolite of allopurinol, is thought to induce immunological reactions and cause tissue damage by developing antibodies against tissues, a decrease of metabolite discharge, and an increase of toxicity in people with renal dysfunction (4).

Generally, DRESS syndrome can be treated with medium- or high-dose oral systemic corticosteroids, but sometimes, other immunosuppressant agents, such as cyclosporine, may be required $(2,6)$. The patients who do not respond to antihistaminics, fluid and steroid treatment, due to liver involvement, intravenous immunoglobulin (IVIG) can be given, being reported to be beneficial for most patients it is used (5). For our case, allopurinol was stopped, and systemic steroids and antihistaminic treatment were started. The patient, who responded favorably to treatment, was discharged with full recovery on the $9^{\text {th }}$ day.

\section{Conclusion}

For patients who are admitted to the emergency department with a history of using allopurinol and having skin lesions and an increase in liver function tests showing involvement of internal organs, DRESS syndrome should be considered.

Informed Consent: Written informed consent was obtained from patient who participated in this case.

Peer-review: Externally peer-reviewed.

Author Contributions: Concept - E.K.; Design - M.G.T.; Supervision H.O.; Materials - S.B.; Data Collection and/or Processing - S.G.; Analysis 
and/or Interpretation - M.G.T; Literature Review - E.K.; Writer - M.G.T.; Critical Review - S.G.

Conflict of Interest: The authors declared no conflict of interest.

Financial Disclosure: No financial support was received for the study.

Hasta Onamı: Yazılı hasta onamı bu olguya katılan hastadan alınmıştır.

Hakem değerlendirmesi: Dış bağımsız.

Yazar Katkıları: Fikir - E.K.; Tasarım - M.G.T.; Denetleme - H.O.; Malzemeler - S.B.; Veri toplanması ve/veya işlemesi - S.G.; Analiz ve/ veya yorum - M.G.T.; Literatür taraması - E.K.; Yazıyı yazan - M.G.T.; Eleştirel İnceleme - S.G.

Çıkar Çatışması: Yazarlar çıkar çatışması bildirmemişlerdir.
Finansal Destek: Olgu için herhangi bir finansal destek alınmamıştır.

\section{References}

1. Bakkal SU, Tufan ZK, Bulut C, Boyraz S, Vahaboğlu G. Sepsisi taklit eden bir DRESS sendromu olgusu. Klimik Dergisi 2011; 24: 132-4.

2. Walsh SA, Creamer D. Drug reaction with eosinophilia and systemic symptoms (DRESS): a clinical update and review of current thinking Clinical and Experimental Dermatology 2010; 36: 6-11. [CrossRef]

3. Um SJ, Lee SK, Kim YH, Son CH, Roh MS, Lee MK. Clinical features of drug-induced hypersensitivity syndrome in 38 patients. J Investig Allergol Clin Immunol 2010; 20: 556-62.

4. Erturan İ, Başkak PY. Allopürinolün indüklediği DRESS sendromu olgusu. Turk J Dermatol 2013; 7: 100-2.

5. Yılmaz EA, Özmen S, Tuygun N, Giniş T, Tanır G. Lamotrijin ilişkili DRESS sendromu: bir vaka sunumu. Çocuk Dergisi 2009; 9: 142-6.

6. Zuliani E, Zwahlen H, Gilliet F, Marone C. Vancomycin-induced hypersensitivity reaction with acute renal failure:resolution following cyclosporine treatment. Clin Nephrol 2005; 64: 155-8. [CrossRef] 